\title{
IMPACT OF AIR POLLUTION TO GENOME OF NEWBORNS
}

\author{
Radim J. Šrám¹, Pavel Rössner, Jr', Andrea Rössnerová1, Miroslav Dostál', Alena Milcová1, Vlasta Švecová1, Jana \\ Pulkrabová2, Jana Hajšlová2, Miloš Velemínský, $\mathrm{Jr}^{3}$ \\ ${ }^{1}$ Institute of Experimental Medicine AS CR, Prague, Czech Republic \\ 2University of Chemistry and Technology, Prague, Czech Republic \\ 3University of South Bohemia, České Budějovice, Czech Republic
}

\begin{abstract}
SUMMARY
The Northern Moravia Region is the most polluted region in the Czech Republic by particulate matter $\left(\mathrm{PM}_{2.5}\right)$ and carcinogenic polycyclic aromatic hydrocarbons (c-PAHs) as benzo[a]pyrene (B[a]P) by heavy industry and local heating. This specific situation was used to study the impact of air pollution on newborns in the exposed Karviná district and control district of České Budèjovice. Biological material from newborns and mothers was collected in summer and winter seasons. This project is highly detailed, analyzing the concentrations of PAHs in ambient air and diet, in human breast milk, in the urine of mothers and newborns, using biomarkers of genetic damage as DNA adducts and gene expression analysis, biomarkers of oxidative stress as 8-oxodG adducts and lipid peroxidation (15-F2t-isoprostane immunoassay). All 400 children, for whom the biomarker data at delivery were obtained, will be followed for morbidity up to 2 years of age. The Northern Moravia Region seems to be to be a model area for studying the long-term impact of human health exposure to c-PAHs. Our observations will indicate possible genetic and oxidative damage in newborns, which may significantly affect their morbidity.
\end{abstract}

Key words: newborns, polycyclic aromatic hydrocarbons, air pollution, diet, molecular epidemiology, genetic damage, oxidative stress

Address for correspondence: R. J. Šrám, Institute of Experimental Medicine AS CR, Vídeňská 1083, 14220 Prague 4, Czech Republic. E-mail: sram@biomed.cas.cz

http://dx.doi.org/10.21101/cejph.a4536

\section{INTRODUCTION}

The effect of in utero environmental exposures on early-life health is growing area of research with major public health implications. Prenatal exposure to certain environmental chemicals, tobacco smoke, and air pollution during critical windows of development can lead to birth defects, low birth weight, impaired growth, immunological disturbances, respiratory symptoms and impaired lung, cognitive and psychomotor development $(1,2)$. Adverse effects can be significant and lead to lifetime chronic effects (3).

Polycyclic aromatic hydrocarbons (PAHs) such as benzo[a] pyrene $(\mathrm{B}[\mathrm{a}] \mathrm{P})$ are carcinogenic environmental pollutants resulting from incomplete combustion that are commonly found in tobacco smoke, ambient and indoor air, and charbroiled food. PAHs are released to atmosphere from local heating, traffic and various industrial sources. Ambient air exposure to PAHs poses a health risk due to their mutagenic, genotoxic and carcinogenic activity, which was detected only during the last two decades. PAHs are metabolized to form a wide range of products including highly reactive epoxides, which have capacity to bind to DNA, forming PAH-DNA adducts $(4,5)$ and induce oxidative damage (6). Using acellular system Binkova et al. (7) observed, that the genotoxicity of respirable particulate matter was related to the content of PAHs. Growing body of evidence suggests that ambi- ent air exposure to $\mathrm{B}[\mathrm{a}] \mathrm{P}$ at levels over $1.0 \mathrm{ng} / \mathrm{m}^{3}$ induces DNA damage (8). Personal exposure to $\mathrm{B}[\mathrm{a}] \mathrm{P}$ over this value predicts greater genomic frequency of translocations (9), micronuclei (10) and DNA fragmentation in sperm (11).

Effect of air pollution seems to be significant to children, who are more sensitive than adults as their organism is in the stage of development. New knowledge about respiratory particles and complex mixtures as represented by PAHs adsorbed on their surface and the use of biomarkers of exposure and effect during the last twenty years were substantial to better understand how air pollution may affect children health already from the beginning of foetal life (12)

Prenatal exposure to ambient air polluted by PAHs has been shown to be associated with reduction in birth weight (intrauterine growth restriction-IUGR), an increased likelihood of low birth weight $(8,13-15) . \mathrm{B}[\mathrm{a}] \mathrm{P}$ concentrations in the umbilical cord blood (UCB) correlated with reduced neonatal height and gestational age (16). In addition to inhalation, also dietary exposure is of concern. In the study context, birth weight was assumed to be affected by consuming barbecued meat (17). Also, sufficient evidence exists of a link between the prenatal exposure to mixtures of carcinogenic PAHs and intrauterine growth restriction in humans (10). Study of nonsmoking women from Beijing proved detectable concentrations of PAHs in breast milk, placenta and umbilical cord blood (18). 
In our recent study (19) we have focused on the effect of exposure to $\mathrm{B}[\mathrm{a}] \mathrm{P}$ to induce changes in DNA adducts, micronuclei and transcriptome in pregnancies from Prague and České Budějovice (CB). Exposure to B[a]P 3 months before delivery was $1.9 \pm 0.5 \mathrm{ng} / \mathrm{m}^{3}$ vs. $3.2 \pm 0.2 \mathrm{ng} / \mathrm{m}^{3}$ for Prague and $\mathrm{CB}$, respectively (winter 2008/2009). Samples obtained from 35 mothers from Prague and 52 mothers from CB were analyzed, all subjects were nonsmokers. DNA adducts were determined by 32P-postlabeling. Levels of total DNA adducts in cord blood were $0.98 \pm 0.89$ vs. $1.40 \pm 1.31 / 108$ nucleotides $(p<0.001)$, in placentas $1.15 \pm 1.06$ vs. $1.94 \pm 1.80 / 108$ nucleotides $(\mathrm{p}<0.001)$, for subjects from Prague and $\mathrm{CB}$, respectively. The frequencies of micronuclei (MN) determined by automated image analysis, as MN per 1000 binucleated cells were $2.17 \pm 1.32 \mathrm{vs.} 3.82 \pm 2.43$ $(\mathrm{p}<0.001)$ for newborns from Prague and CB, respectively (20). Using microarrays, we assayed the whole genome gene expression profiles in the peripheral blood and placentas of the mothers, and in the cord blood of their newborns. Comparative analysis of the profiles between the areas indicated that the pregnancies from $\mathrm{CB}$ showed up-regulation of activity of genes associated with exposure to genotoxic compounds (e.g., genes for xenobiotic enzymes, compensation of oxidative stress, and inflammatory factors), in the cord blood down-regulation of genes related to immune response occurred. This finding corresponded with the increased level of DNA adducts as well as micronuclei detected in the cord blood from CB. Therefore, we hypothesize that the analysis of gene expression seems to be the new biomarker of air pollution.

To verify this knowledge, we have studied the impact of exposure to $\mathrm{B}[\mathrm{a}] \mathrm{P}$ in ambient air in $\mathrm{CB}$ and Karviná, where the concentration of the pollutant was 5-6 times higher than in $\mathrm{CB}$ in the year 2011 (21). This study will analyze for the first time the relationship between gene expression changes in newborns and their morbidity in early life.

\section{Hypothesis}

1. Increased exposure to c-PAHs during pregnancy affects gene expression in newborns and their morbidity in early life.

2. DNA damage in mothers and newborns is related to exposure to c-PAHs occurring in the ambient air.

3. Gene expression changes induced by the exposure to c-PAHs during pregnancy influence pathways affecting immunity.

4. Expression of genes in cord blood affected by c-PAHs could be used as a new biomarker of exposure to c-PAHs.

\section{METHODS}

\section{Subjects}

The samples were collected in the Hospital České Budějovice, Department of Obstetrics and Department of Neonatology, and in the Hospital Karviná, Department of Obstetrics and Department of Neonatology. The study was approved by the Ethical Committee of both hospitals.

The samples from normal deliveries (38-41 week+) of nonsmoking mothers were collected in the summer 2013 and winter 2014 seasons. The samples included venous blood, milk and urine from 100 mothers at České Budějovice and 100 mothers at Karviná in each season (total 1200 samples) and cord blood (8 $\mathrm{ml}$ ) from 100 newborns at České Budějovice and 100 newborns at Karviná in each season (total 400 samples). Blood was collected to EDTA and heparin tubes for isolation of DNA and plasma. To separate the leukocytes from the whole blood samples and isolate RNA, the LeukoLOCKTM Total RNA Isolation System (Ambion Inc., Austin, TX, USA) was used. Milk (20 ml) was collected from mothers before leaving hospital. All mothers signed the consent forms establishing agreement to their participation in study, collection of biological samples, and providing information about the health of their children for up to 2 years of age. Mothers completed in hospital mother's questionnaires. Obstetricians and pediatricians completed the corresponding questionnaires about the mother's pregnancy, delivery and the health status of newborns.

The children will be monitored for up to 2 years of age for their morbidity via questionnaires filled out by their pediatricians.

\section{Air Sampling}

c-PAHs bound to particulate matter $\leq 2.5 \mu \mathrm{m}\left(\mathrm{PM}_{2.5}\right)$ were collected by a High Volume Air Sampler (model ECO-HVS3000, Ecotech, Australia) on Pallflex membrane filters (EMFAB, TX40HI20-WW) for 2 months in the period of biological samples collection (22).

\section{DNA Adducts}

The analysis of PAH-DNA adduct formation by 32P-postlabeling method was performed according to a standard procedure $(7,23)$. DNA was isolated from peripheral lymphocytes, and enriched by nuclease $\mathrm{P} 1$. The $32 \mathrm{P}$-radioactivity will be measured by liquid scintillation counting. The data are expressed as the total and "B[a]P-like" DNA adduct levels.

\section{8-oxodG Adducts}

Oxidative DNA damage, measured as levels of 8-oxodG (8-oxo-7,8-dihydro-2'-deoxyguanosine) in DNA from urine samples was analyzed using competitive ELISA with the primary antibody N45.1 (concentration $0.2 \mu \mathrm{g} / \mathrm{ml}$, JaICA, Japan) as described by Rossner et al. (24). Each sample was analyzed in triplicate. 8-oxodG levels are expressed as the number of 8-oxodG molecules per 105 guanosine molecules (8-oxodG/105 dG).

\section{5-F2t-isoprostane Immunoassay}

Blood plasma 15-F2t-isoprostane levels (15-F2t-IsoP), a marker of lipid peroxidation, was analyzed using immunoassay kits from Cayman Chemical Company (Ann Arbor, MI, USA, cat. no 516351) according to the manufacturer's protocol. Each sample will be analyzed in duplicate. The 15-F2t-IsoP concentrations are expressed as pg 15-F2t-IsoP/ml plasma (25).

\section{Cotinine Analysis}

Plasma cotinine levels as a marker of active and passive smoking were analyzed by radioimmunoassay (26). 


\section{Gene Expression Analysis}

The extraction of leukocyte RNA was conducted using LeukoLOCK Total RNA Isolation System (AMBION) according to the manufacturer's recommendations. RNA was quantified spectrophotometrically using a Nanodrop ND-100 Spectrophotometer (Thermo Fisher Scientific, Waltham, MA, USA). RNA integrity number (RIN) were determined using an Agilent 2100 Bioanalyzer (Agilent Technologies Inc., Santa Clara, CA, USA). Samples with RIN lower than 5.0 were excluded. Total RNA (200 ng) was converted into cRNA using Illumina TotalPrep RNA Amplification Kit (Ambion). cRNA (750 ng) was hybridized onto beadchips overnight according to the Illumina manual. Gene expression profiles were assayed using HumanHT-12 v4 Expression BeadChips (Illumina, San Diego, CA, USA) containing probes for more than $48 \mathrm{k}$ transcripts. The beadchips were scanned on the Illumina BeadArray Reader. Raw data were extracted by Illumina BeadStudio Software v3, and were further processed by Genedata.

\section{Quantitative Real-time Polymerase Chain Reaction (qRT-PCR)}

Microarray data will be validated by qRT-PCR. We will select several genes with diverse functions which are affected (either up- or down-regulated). The Transcriptor High Fidelity cDNA synthesis Kit (ROCHE, Mannheim, Germany) will be used for reverse transcription of total RNA according to manufacture protocol modified by Rossner et al. (27). For all qPCR measurements, the 7900HT Fast Real-Time PCR System (Applied Biosystems, Carlsbad, CA, USA) were used.

\section{Statistical Data Analysis (by Genedata AG, Basel)}

Integrated analysis of gene expression data in conjunction with clinical parameters, PAH-DNA adducts and oxidative stress data were performed using the Genedata Expressionist ${ }^{\circledR}$ platform.

Illumina Expression BeadChips results were analyzed using linear models taking into account measured covariates (PAHDNA adducts, 8-oxodG, 15-F2t-isoprostane), fixed factors like sex, delivery conditions, and potential confounding factors. Such confounding and/or fixed factors are detected using different statistical approaches like Partial Least Square Analysis, Principal Components Analysis, clustering methods, etc. Another approach is to search directly for correlations between gene expression patterns and covariates (8-oxodG, 15-F2t-isoprostane).

Gene expression changes of selected genes measured by qRTPCR are also analyzed for significance using statistical tests like Student's t-test or with more sophisticated linear models taking into account covariates, fixed factors, and confounding factors as described before.

The outcomes of the statistical analyses of the gene expression data are visualized by mapping them onto a reference genome. This will allow an easier biological interpretation of the results from the statistical analyses.

\section{Child Morbidity}

All 400 children, for whom the biomarker data at delivery will be obtained, will be followed for morbidity for up to 2 years of age, if approved by the informed consent of both parents. When possible, this cohort will be further studied during the preschool age. When the children in the study reach the age of 2 years, the pediatricians will be asked to fulfill the questionnaires about their development and morbidity. The respective pediatricians will be notified shortly after the birth of the children so that they will be attentive to maintain detailed medical records for their patients who are part of this study. Analysis of morbidity of children will be based on complete abstractions of ICD-10 codes and dates of all illnesses. Maternal questionnaires administered after the children reached 2 years of age will ask about the life style of family.

\section{Analysis of PAHs in HiVol Samples}

The current method including 16 EPA PAHs were extended to cover all c-PAHs according to IARC list. For PAHs isolation by Soxhlet extraction or sonication hexane, dichloromethane or their mixtures were tested. The crude extracts were purified using gel permeation chromatography (GPC) or by solid phase extraction (SPE) on florisil or silicagel column. The analytes were determined using modern gas chromatography coupled with tandem mass spectrometry (GC-MS/MS, GC Agilent 7890 with triple quadrupole 7000B or GCT Premier, Waters.

\section{Analysis of PAHs in Urine}

In mothers' and children urine c-PAHs and their $\mathrm{OH}$, di-OH, di-OH epoxy, tetra-OH metabolites were analyzed. After the enzymatic hydrolysis, the target analytes were extracted/concentrated from the urine using SPE. The identification and quantitation of $\mathrm{OH}-\mathrm{PAHs}$ were performed using liquid chromatography coupled with tandem mass spectrometry. (LC-MS/MS, Xevo TQ-S/ UPLC Acquity or AB SCIEX 5500 QTRAP MS/UPLC Acquity). Since standards are not available for all metabolites; also liquid chromatography coupled with high resolution MS (HRMS) were used for non-target screening Synapt G2 HDMS/UPLC Acquity (Waters). These data were also utilized for non-target analysis in the case of detection of extensive gene deregulation, which will not be related to c-PAHs exposure.

\section{Analysis of PAHs in Human Breast Milk}

Both parent compounds (c-PAHs) and their hydroxy-metabolites were analyzed in the human breast milk samples. Since the amount of sample was limited, a new sample preparation procedure was developed in the first part of the project. For isolation of analytes SPE or a modified QuEChERS method employing ethylacetate or acetonitrile extraction was used. In the latter case dispersive SPE was applied for clean-up of primary extract. The final measurements was done on both GC-MS/MS (GC Agilent 7890 with triple quadrupole 7000B or GCT Premier) and LC-MS/ MS (Xevo TQ-S/UPLC Acquity or AB SCIEX 5500 QTRAP MS /UPLC Acquity) based on the type of analyte.

\section{Analysis of PAHs in Diet}

Altogether 19 PAHs were analyzed: acenaphtene, acenaphtylene, anthracene, fluoranthene, fluorene, naphthalene, fenanthrene, pyrene, benz[a]anthracene, benzo[a]pyrene, benzo[b]fluoranthene, benzo[j]fluoranthene, benzo[g,h,i] 
perylene, chrysene, dibenz[a,h]anthracene, indeno[1,2,3-cd] pyrene, benzo[c]fluorine,benzo[k]fluoranthene, cyklopenta[c,d] pyrene,dibenzo[a,e]pyrene, dibenzo[a,h]pyrene, dibenzo[a,i] pyrene, dibenzo[a,1]pyrene,5-methylchrysene. Crude extracts were purified by silicagel column. The final measurements was done on GC-MS/MS (GC Agilent 7890 with triple quadrupole 7000B or GCT Premier).

\section{RESULTS}

During the sampling periods, the concentrations of $\mathrm{PM}_{2.5}$ in summer were $21.54 \pm 11.78 \mu \mathrm{g} / \mathrm{m}^{3}$ in Karviná, $12.14 \pm 7.23$ $\mu \mathrm{g} / \mathrm{m}^{3}$ in České Budějovice, in winter $55.35 \pm 38.74 \mu \mathrm{g} / \mathrm{m}^{3}$ and $26.39 \pm 16.85 \mu \mathrm{g} / \mathrm{m}^{3}$, respectively. Concentrations of $\mathrm{B}[\mathrm{a}] \mathrm{P}$ in summer were $1.31 \pm 1.26 \mathrm{ng} / \mathrm{m}^{3}$ in Karviná, $0.44 \pm 0.63 \mathrm{ng} / \mathrm{m}^{3}$ in České Budějovice, in winter $5.15 \pm 5.47 \mathrm{ng} / \mathrm{m}^{3}$ and $1.43 \pm 1.37$ $\mathrm{ng} / \mathrm{m}^{3}$, respectively.

We collected in summer 71 samples in Karviná and 99 samples in České Budějovice, in winter, 73 samples in Karviná and 99 samples in České Budějovice.

Analysis of DNA adducts, 8-oxodG adducts, 15-F2t-isoprostane, cotinine and gene expression are already finished, going through statistical evaluation. Similarly analysis of PAHs in human breast milk and diet are finished, going through statistical evaluation. Analysis of PAHs in urine is going on. Child morbidity data will be collected from autumn 2015, when first children will reach age 2 years.

\section{CONCLUSION}

When we obtain all results, it will be a very unique study, analyzing the impact of PAHs from ambient air and diet to mothers and newborns. The Northern Moravia Region seems to be a model area to study the long-term impact of c-PAHs exposure to human health.

\section{Acknowledgements}

The study is supported by the Grant Agency of the Czech Republic P30113-13458S. The authors deeply appreciate the support of Dr Radek Sušil, vice-director of Hospital Karviná-Ráj and Dr Břetislav Schon, Director of Hospital České Budějovice. The study would not have been possible without the close cooperation of all obstetricians, pediatricians, nurses and laboratory workers in both hospitals.

\section{Conflict of Interests}

None declared

\section{REFERENCES}

1. Wild CP, Kleinjans J. Children and increased susceptibility to environmental carcinogens: evidence or empathy? Cancer Epidemiol Biomarkers Prev. 2003 Dec;12(12):1389-94.

2. Nieuwenhuijsen MJ, Dadvand P, Grellier J, Martinez D, Vrijheid M. Environmental risk factors of pregnancy outcomes: a summary of recent meta-analyses of epidemiological studies. Environ Health. 2013 Jan 15;12:6. doi: 10.1186/1476-069X-12-6.
3. Gluckman PD, Hanson MA, Cooper C, Thornburg KL. Effect of in utero and early-life conditions on adult health and disease. N Engl J Med. 2008 Jul 3;359(1):61-73.

4. Topinka J, Binková B, Mracková G, Stávková Z, Peterka V, Benes I, et al. Influence of GSTM1 and NAT2 genotypes on placental DNA adducts in an environmentally exposed population. Environ Mol Mutagen. 1997;30(2):184-95.

5. Whyatt RM, Bell DA, Jedrychowski W, Santella RM, Garte SJ, Cosma G, et al. Polycyclic aromatic hydrocarbon-DNA adducts in human placenta and modulation by CYP1A1 induction and genotype. Carcinogenesis. 1998 Aug;19(8):1389-92.

6. Rossner P Jr, Tabashidze N, Dostal M, Novakova Z, Chvatalova I, Spatova $\mathrm{M}$, et al. Genetic, biochemical, and environmental factors associated with pregnancy outcomes in newborns from the Czech Republic. Environ Health Perspect. 2011 Feb;119(2):265-71.

7. Binková B, Cerná M, Pastorková A, Jelínek R, Benes I, Novák J, et al. Biological activities of organic compounds adsorbed onto ambient air particles: comparison between the cities of Teplice and Prague during the summer and winter seasons 2000-2001. Mutat Res. 2003 Apr 9;525(12):43-59.

8. World Health Organization. WHO guidelines for indoor air quality: selected pollutants. Copenhagen: WHO Regional Office for Europe; 2010.

9. Sram RJ, Beskid O, Binkova B, Chvatalova I, Lnenickova Z, Milcova A et al. Chromosomal aberrations in environmentally exposed population in relation to metabolic and DNA repair genes polymorphisms. Mutat Res. 2007 Jul 1;620(1-2):22-33.

10. Rossnerova A, Spatova M, Rossner P, Solansky I, Sram RJ. The impact of air pollution on the levels of micronuclei measured by automated image analysis. Mutat Res. 2009 Oct 2;669(1-2):42-7.

11. Rubes J, Rybar R, Prinosilova P, Veznik Z, Chvatalova I, Solansky I, et al. Genetic polymorphisms influence the susceptibility of men to sperm DNA damage associated with exposure to air pollution. Mutat Res. 2010 Jan 5;683(1-2):9-15

12. Lewtas J. Air pollution combustion emissions: characterization of causative agents and mechanisms associated with cancer, reproductive, and cardiovascular effects. Mutat Res. 2007 Nov-Dec;636(1-3):95-133.

13. Dejmek J, Solanský I, Benes I, Lenícek J, Srám RJ. The impact of polycyclic aromatic hydrocarbons and fine particles on pregnancy outcome. Environ Health Perspect. 2000 Dec;108(12):1159-64.

14. Choi H, Perera F, Pac A, Wang L, Flak E, Mroz E, et al. Estimating individual-level exposure to airborne polycyclic aromatic hydrocarbons throughout the gestational period based on personal, indoor, and outdoor monitoring. Environ Health Perspect. 2008 Nov;116(11):1509-18.

15. Choi H, Wang L, Lin X, Spengler JD, Perera FP. Fetal window of vulnerability to airborne polycyclic aromatic hydrocarbons on proportional intrauterine growth restriction. PLoS One. 2012;7(4):e35464. doi: 10.1371/ journal.pone.0035464.

16. Guo Y, Huo X, Wu K, Liu J, Zhang Y, Xu X. Carcinogenic polycyclic aromatic hydrocarbons in umbilical cord blood of human neonates from Guiyu, China. Sci Total Environ. 2012 Jun 15;427-428:35-40.

17. Jedrychowski W, Perera FP, Tang D, Stigter L, Mroz E, Flak E, et al. Impact of barbecued meat consumed in pregnancy on birth outcomes accounting for personal prenatal exposure to airborne polycyclic aromatic hydrocarbons: Birth cohort study in Poland. Nutrition. 2012 Apr;28(4):372-7.

18. Yu Y, Wang X, Wang B, Tao S, Liu W, Wang X, et al. Polycyclic aromatic hydrocarbon residues in human milk, placenta, and umbilical cord blood in Beijing, China. Environ Sci Technol. 2011 Dec 1;45(23):10235-42.

19. Sram RJ, Binkova B, Dostal M, Merkerova-Dostalova M, Libalova H, Milcova A, et al. Health impact of air pollution to children. Int J Hyg Environ Health. 2013 Aug;216(5):533-40.

20. Rossnerova A, Spatova M, Pastorkova A, Tabashidze N, Veleminsky M Jr, Balascak I, et al. Micronuclei levels in mothers and their newborns from regions with different types of air pollution. Mutat Res. 2011 Oct $1 ; 715(1-2): 72-8$.

21. Czech Hydrometeorological Institute. Air pollution and atmospheric deposition in data, the Czech Republic [Internet]. Prague: Czech Hydrometeorological Institute; 2014 [cited 2015 Oct 30]. Available from: http:// portal.chmi.cz/files/portal/docs/uoco/isko/tab_roc/tab_roc_EN.html.

22. Topinka J, Rossner P Jr, Milcova A, Schmuczerova J, Svecova V, Sram RJ. DNA adducts and oxidative DNA damage induced by organic extracts from PM2.5 in an acellular assay. Toxicol Lett. 2011 May 10;202(3):18692.

23. Binkova B, Chvatalova I, Lnenickova Z, Milcova A, Tulupova E, Farmer $\mathrm{PB}$, et al. PAH-DNA adducts in environmentally exposed population in 
relation to metabolic and DNA repair gene polymorphisms. Mutat Res. 2007 Jul 1;620(1-2):49-61.

24. Rossner P Jr, Milcova A, Libalova H, Novakova Z, Topinka J, Balascak I, et al. Biomarkers of exposure to tobacco smoke and environmental pollutants in mothers and their transplacental transfer to the foetus. Part II. Oxidative damage. Mutat Res. 2009 Oct 2;669(1-2):20-6.

25. Rossner P Jr, Svecova V, Milcova A, Lnenickova Z, Solansky I, Sram RJ. Seasonal variability of oxidative stress markers in city bus drivers. Part II. Oxidative damage to lipids and proteins. Mutat Res. 2008 Jul $3 ; 642(1-2): 21-7$

26. Langone JJ, Van Vunakis H. Radioimmunoassay of nicotine, cotinine, and gamma-(3-pyridyl)-gamma-oxo-N-methylbutyramide. Methods Enzymol. 1982;84:628-40.
27. Rossner P Jr, Uhlirova K, Beskid O, Rossnerova A, Svecova V, Sram RJ Expression of XRCC5 in peripheral blood lymphocytes is upregulated in subjects from a heavily polluted region in the Czech Republic. Mutat Res. 2011 Aug 1;713(1-2):76-82.

Received August 28, 2015 Accepted in revised form October 30, 2015 